\title{
素線絶縁大導体電力ケーブルの交流実効 抵抗の計算法の開発
}

論 文

58-B 72
正員 松 浦 虔
（大阪大）正員木原 登喜夫
(福井工大)
正員横山弘道
(住友電工) ・非会員
盛山吉 博
(住友電工)
正員 宮 崎 俊 博
(住友電工) ・正員
伊 藤
哲 二
(住友電工)

\section{1. まえがき}

電力ケーブル用の導体は，商用周波数においてむ， 断面積が $1,000 \mathrm{~mm}^{2}$ 以上になる上非分割形では表皮 勃果が著しくなるため，链来から導体を分割形しし， 表皮効果つまり交流実効抵抗の低減を図っている。竡 体断面皘が，最高 $2,000 \sim 2,500 \mathrm{~mm}^{2}$ 程度であれば， 畋用の 4 防至 6 分割形で対好できると考えられるか， 近年の送電容量の増大傾向に伴い，電力ケーブルの導 体には罗来更に大サイズのものも要求されよう。

また，許容電流のみな゙らず，昨今のエネルギー事情 から省エネルギーの観点でも，表皮效果の低隇が重要 な課題となってきている。そこで, 現用の導体よりる 更に一尿の表皮効果乃至は交流実効抵机の低减を図る ことを目的とした種々の手法が提案されている(1)〜(3)。

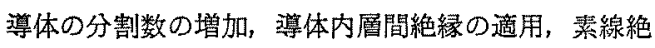
縁などという手法がそれである。

一方，導体の交流実効抵抗の計算式は，JCS-168号 (日本電線工業会規格：許容電流)などに記述されてい $ろ^{(4)(5)}$ 。しかし，乙の計算式は，円柱導体の表皮効果 理論式と㬰際の導体に関する抵抗測定加ら求めた補正 係数とを組み合わせた半経験式であるため，適用筙囲 は限られる。良って，前述のような新手法を導入した 大導体に対しては不十分な要ので，新しい理諭計算式 の開発が待望されている。新しい理諭計算式としては

\footnotetext{
Development of Calculation Method for AC Resistance of Power Cable Conductors with Insulating Coating Applied on Strands. By Kenji Matsuura, Member (Department of Electrical Engineering, Osaka University), Tokio Kihara, Member (Department of Electrical Engineering, Fukui Institute of Technology), Hiromichi Yokoyama, Member, Yoshihiro Moriyama, NonMember, Toshihiro Miyazaki, Member \& Tetsuji Itoh, Member (Sumitomo Electric Industries, LTD).

松浦度士：正真，大陌大学工学部臂気工学科

木原登喜夫：正貴，福茾工落大学

横山弘道：正員，住友電気工業秼式会社

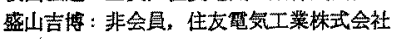

富䗁後博：正員，住友要気工業式会社

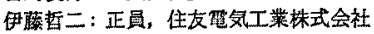

基本的には，分割導体の形状および素線配列に関する 情報をそのまま計算式の中にとり入れ，各素線への電 流分布および素線内電流密度分布を算出できるすのが 望ましい。

そてで，著者らは，第一段階として索線絶縁分割導 体について，上述の上うな考元方に基つ゚いた従来にな い新しい交流実效抵抗の理論計算式を導出した。本論 文では，その導出の過程を述べると共に，理論の妻当 性を実験などで検証した結果について報告する。

\section{2. 交流実効抵抗の理論式の導出}

全体の外形が円形の素線絶縁分割導体の交流実效抵 抗の新しい計算式を以下に導出する。基本的な考元方 は，各素線に流れる電流を，素線の導体断面および長 さ方向の幾何学的配列を考慮して決定するという点に ある。なお，各菜線の断面に流れる電流は，相電流成 分とうず電流成分の 2 成分からなっているものとして 交流実効抵抗沶上び表皮効果係数を算出する。

〈2.1〉 計算対象導体導体配列を図 1 に示した。 導体は， $X$ 相， $Y$ 相， $Z$ 相の三相導体で構成され，図 中の角度 $\theta$ は任意の值をとれるものとする。また， $X, Y, Z$ 各相の導体には，それぞれ相電流 $\dot{I}_{X}, \dot{I}_{Y}, \dot{I}_{Z}$ が流れており, 三相平衡条件 $\dot{I}_{X}+\dot{I}_{Y}+\dot{I}_{Z}=0$ が満た されているとする。交流実効抵抗の計算対象は $X$ 相 導体とする。

〈2・2〉セグメント導体の素線構成 図 2 亿示す ように，1 セグメントの全素線周列の数を $n$ とし，最 外周列の素線群(1)を第 1 周，更们内側へ向って素線群 (2)を第 2 周，……最内周素線(20を第 $n$ 周と呼方とと にする。(1)（2)，, 岛-1) の各素線は，それぞれ長さ方 向に各々一定のピッチでねん架が行なわれている。

第 $h$ 周 $(h=1,2, \cdots, n)$ の全素線数を $M_{h}$ 本とする。

次に，導体中心に最正近い同一円弧上にある素線の 並びを第 1 層と呼ふことにし，更に導体外側に向って

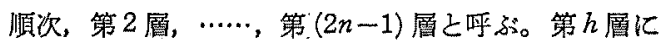




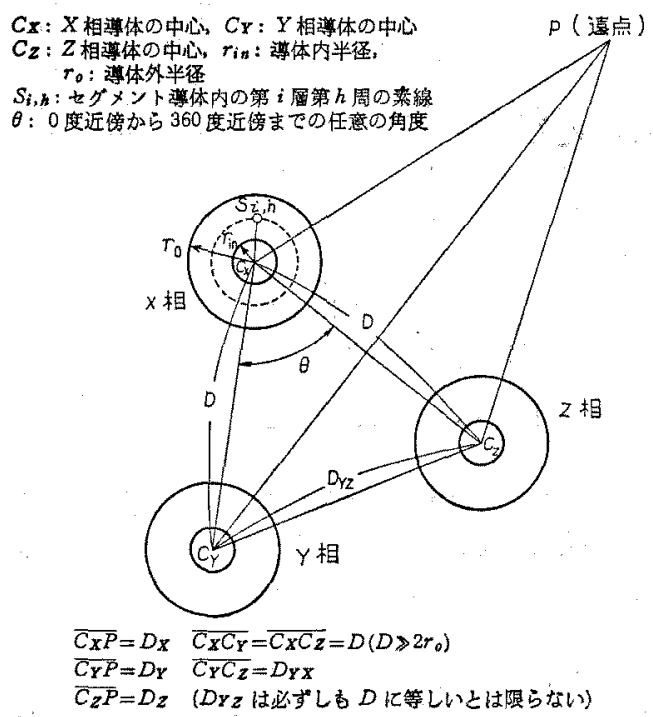

図 1 導体配列

Fig. 1. Layout of conductors.

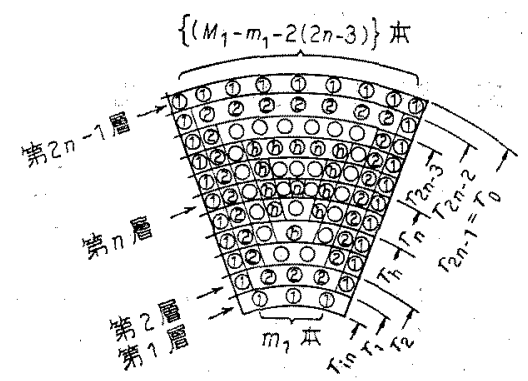

(1)：第 1 周の素線，(2): 第 2 周の繁線

(b)：第 $h$ 周の䐯線，(B)：第 $n$ 周の祭線

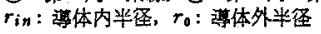

因 2 セグメント導体内の素線構成

Fig. 2. Formation of strands in one segment.

位置する第 $h$ 周の素線の数を $m_{h}$ 本とする。こうする 之，第 $h$ 周の素線群のうち，第 $(2 n-h)$ 層任位置する 素線の本数は， $\left\{M_{h}-m_{h}-2(2 n-2 h-1)\right\}$ 本である (但し, $h=1,2, \cdots, n-1$ )。 $h=n$ の場合は $M_{n}=1$ で あり，第 $n$ 首第 $n$ 周の位置にのみ 1 本の素線が存在す る。

$\langle 2$-3〉相電流の各素線への分布 上述の菜線配 列を考慮すれば，同一周に属する各菜線には等しい電 流か流れると考えられる。そとで，第ん周 $(h=1,2$, $\cdots, n)$ の素線 1 本に流れる電流を $\dot{a}_{h} \dot{I}_{X}$ とする。 $\dot{a}_{h}$ 少 求まれば，相電流の各素線への分布が決定されるとと になる。 $\dot{a}_{h}$ は次の上うにして求められる。

導体単位長さの電圧降下量を $\dot{V}\left(=v_{\mathrm{r}}+j v_{\text {n }}\right)$ とし, 第 $h$ 周の素線 1 本に銷交する単位長平均磁束を $\dot{\phi}_{h}$ 之
すると次式が成り立つ。

$$
R_{h} \dot{\alpha}_{h} \dot{I}_{\mathrm{X}}+j \omega \dot{\phi}_{h}=v_{\mathrm{I}}+j v_{\mathrm{II}}(h=1,2, \cdots, n)
$$

但し， $R_{A}$ 沈該菜線 1 本の導体単位長当りの直流抵 抗である。 $\dot{I}_{x}$ は実軸上にとり，Ixとしても一般性を 失わないので，以㣪 $\dot{I}_{X}=I_{X}$ とする。 $\dot{a}_{h}$ は， $\alpha_{k}$ と $\beta_{h}$ を実数とし，次式であらわす。

$$
\dot{a}_{h}=\alpha_{h}+j \beta_{h}(h=1,2, \cdots, n) .
$$

次化, 電流 $\dot{I}_{X}, \dot{I}_{Y}, \dot{I}_{Z}$ 名作磁束のう方, 図 1 亿示 した素線 $S_{i, h}$ に銷交する磁束をそれぞれ $\phi_{X i}, \phi_{Y i}$, $\phi_{Z i}$ とし，素線 $S_{i, h}$ 亿おいて素線内電流と鎖交する 磁束を $\phi_{i n t}$ 之する。そして，菜線 $S_{i, 4}$ 汇鎖交する全 磁束 $\phi_{i, \mathrm{a}}\left(=\dot{\phi}_{X i}+\dot{\phi}_{Y i}+\dot{\phi}_{z i}+\phi_{i a t}\right)$ を，素線 $S_{i, \mathrm{~h}}$ の 1 ピッチの長さ区間において平均化すると $\phi_{h}$ が求まり 結果は(3)式であらわされる。

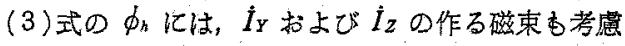
しているので，近接効果も考虑したことになる。また 実験でょく用いられる単相往復回路の場合です， $\phi_{h}$ は (3)式と全く同じ形の式になる。

$$
\phi_{h}=\phi_{h I}+j \phi_{h \text { II }}
$$

但L;

$$
\begin{aligned}
\phi_{h \mathrm{I}}= & \left\{\left(\sum_{j=1}^{n} \psi_{h j} \alpha_{j}\right)+(\mu / 2 \pi) \ln \left(D / r_{0}\right)\right\} I_{x} \\
\dot{\phi}_{h \mathrm{I}}= & \left(\sum_{j=1}^{n} \phi_{h j} \beta_{j}\right) I_{X} \\
\phi_{h j}= & \left(u / M_{h}\right)(\mu / 4 \pi)\left\{\left(r_{0}-r_{i n}\right) /(2 n-1)\right\} \\
& \times\left[m_{h} \sum_{k=h}^{2 n-2}\left(w_{j, k}+w_{j, k+1}\right)\right.
\end{aligned}
$$

\begin{tabular}{|c|c|}
\hline 記 号 & 説 \\
\hline$\phi_{h}$ & 第 $h$ 周に属する索線 1 本化銷交する単位長平均磁東 \\
\hline$\phi_{h \mathrm{I}}$ & $\phi_{h}$ の実数部 \\
\hline$\phi_{h \mathbf{I I}}$ & $\phi_{h} の$ 虚数部 \\
\hline$\dot{a}_{j}$ & 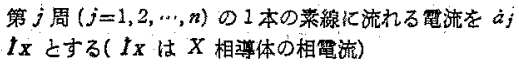 \\
\hline$\alpha_{j}$ & $\dot{a}_{j}$ の実数部 \\
\hline$\beta_{j}$ & $\dot{a}_{j}$ の虚数部 \\
\hline$u$ & 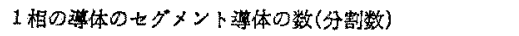 \\
\hline$n$ & 一つのセダメント導体の周の数 \\
\hline$M_{h}$ & 第 $h$ 周に属する秦線の本数 \\
\hline$m_{h}$ & 第 $h$ 層に位酎する第 $h$ 周の素線の本数 \\
\hline$l j, k$ & 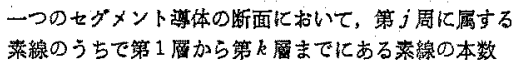 \\
\hline$w_{j, k}$ & $l_{j, k} / r_{k}$ \\
\hline$B_{k}$ & 第 $k$ 瓷之第 $(k+1)$ 層の境界部分の碝東密实 \\
\hline$\mu$ & 萝線の透磁率 \\
\hline$\rho$ & 素線の抵抗率 \\
\hline$R_{h}$ & 第 $h$ 周の索線 1 本の䀤体単位長当り直流抵抗 \\
\hline$\omega$ & 解周波数 $(=2 \pi f)$ \\
\hline
\end{tabular}

表 1 記号の説明(図 1〜因3亿示した記号估除く)

Table 1. List of symbols. 


$$
\begin{aligned}
& +2 \sum_{k=h+1}^{2 n-2}\left(w_{j, k}+w_{j, k+1}\right)+\cdots \\
& +2 \sum_{k=2 n-h-1}^{2 n-2}\left(w_{j, k}+w_{j, k+1}\right) \\
& +\left\{M_{k}-m_{h}-2 \times(2 n-2 h-1)\right\} \\
& \quad \times \sum_{k=2 n-h}^{2 n-2}\left(w_{j, k}+w_{j, k+1}\right)+K\left(M_{h} / u\right) \\
& \left.\quad \times\left\{(2 n-1) / 2 u\left(r_{0}-r_{i n}\right)\right\}\right] \\
& (h=1,2, \cdots, n, \text { 但し } j \neq h \text { の場合 } K=0, j
\end{aligned}
$$$$
=h \text { の場合 } K=1 \text { ) }
$$

上式の中にあらわれる記号の意味は表1 に示すとお
りである。更に，1本の導体のセグメントの合部数か u個であることから

$$
u \sum_{j=1}^{n} M_{j} \alpha_{j}=1, \quad u \sum_{j=1}^{n} M_{j} \beta_{j}=0
$$

また，

$$
v_{1} / I_{X}=\gamma_{1}, v_{\square} / I_{X}=\gamma_{2}
$$

とおく之，(1) (5) 式から， $2 n+2$ 個の未知数 $\left(\alpha_{1}\right.$, $\alpha_{2}, \cdots, \alpha_{n}, \beta_{1}, \beta_{2}, \cdots, \beta_{n}$ および $\left.\gamma_{1}, \gamma_{2}\right)$ に対し，(6)式 で示す $2 n+2$ 元の連立一次方程式が得られる。

（6）式を解けば，相電流の各素線への分布が決定さ れる。

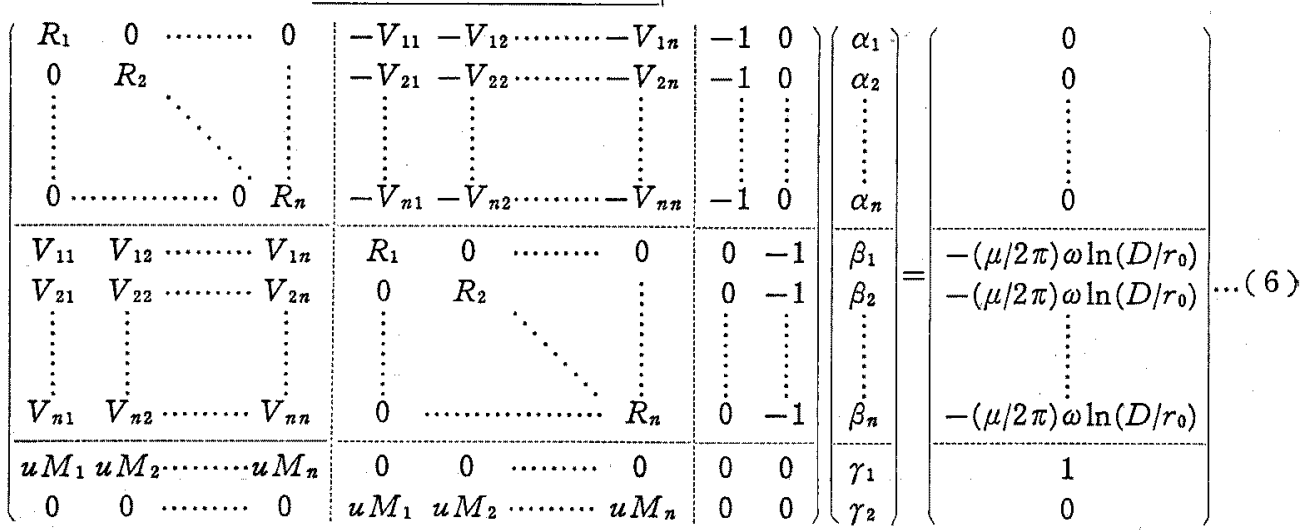

但し, $V_{h j}=\omega \psi_{h j}(h, j=1,2, \cdots, n)$

〈2.4〉 素楾内うず電流分布 $X$ 相導体に流れる 相電流に上る磁束密度のみを考慮し，X相導体内の第 $i$ 層第 $h$ 周の素線 $S_{i, h}$ に生ずるうず電流の密度分布 を計算する。 $Y$ および $Z$ 相電流の影響は，相間距離 が導体径化比し十分大きい場合を想定し無視する。乙

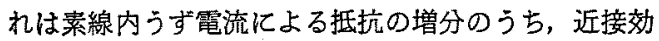
果による分を無視することを意味するが，相間距離が 導体平均半径の 10 倍程度以上ならば，乙の分は極め て小さく無視しても実用上問題とならない。

図3 は，素線 $S_{i, b}$ 内のうず電流分布を計算するた めに設定した座標系を示す。導体中心から半径方向に 沿って，素線 $S_{i, \Delta}$ の中心0を基点とした座標 $x$ を 設定する。菜線内うず電流回路のリアクタンス分は抵 抗分に比し，極めて小さいので， $x$ の位置の斜線で示 した厚さ $d x$ のシート状の部分に流れるうず電流の 密度を $\dot{I}_{x i}$ こする。

さて，導体単位長当り図3の斜線で摤まれた部分に 銷交する磁束 $\dot{\phi}_{i}$ は，平均化近似をして次式で計算さ 机る。

$$
\phi_{i}=x\left(\dot{B}_{i-1}+\dot{B}_{i}\right)
$$

但し， $\dot{B}_{i-1}$ 书よび $\dot{B}_{i}$ は，それぞれ第 $(i-1)$ 層と
第 $i$ 層の境界部分㧍よび第 $i$ 層之第 $(i+1)$ 層の境界部 分における磁束密度である。

常温以上の銅あるいはアルミ導体を対象と考えた場 合，図 3 斜線部分で構成されるうず電流回路のリアク タンス分は素線径が小さいので，抵抗分比比して無視 できる。従って， $\dot{\phi}_{i}$ と $\dot{I}_{x i}$ の間には次の関係が成り 立つ。

$2 \rho \dot{I}_{x i}=j \omega \dot{\phi}_{i}$

一方，第 $j$ 周の素線 1 本に流れる電流が $\dot{a}_{j} I_{x}$ であ

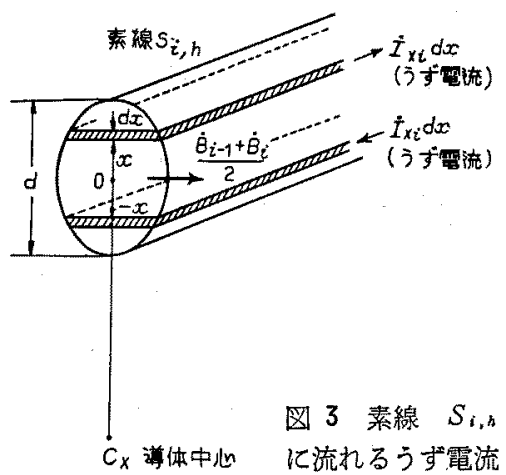

Fig. 3. Eddy current circulating in the strand of $S_{i, h}$. 
り，全セグメント個数が $u$ であるから $\dot{B}_{i}, \dot{B}_{i-1}$ は各 電流成分によって生ずる磁束密度を積算し，次式で晋 らわせる。

$$
\begin{aligned}
& \dot{B}_{i}=(u \mu / 2 \pi) I_{X} \sum_{j=1}^{n} w_{j, i} \dot{a}_{j} \\
& \dot{B}_{i-1}=(u \mu / 2 \pi) I_{x} \sum_{j=1}^{n} w_{j, i-1} \dot{a}_{j} \\
& \text { (7) (9)式加号 } \dot{I}_{x i} \text { 吕次の上う比求まる。 } \\
& \dot{I}_{x i}=j(\omega / \rho)(\mu / 4 \pi) u\left\{\left(\sum_{j=1}^{n} w_{j, i-1} \dot{a}_{j}\right)\right. \\
& \left.+\left(\sum_{j=1}^{n} w_{j, i} \dot{a}_{j}\right)\right\} I_{X} x
\end{aligned}
$$

$\langle 2 \cdot 5\rangle$ 交流実勃抵抗およひ表皮効果係数 図 3 亿示した素線 $S_{i, h}$ 亿抬りる座標 $x$ での素線長さ方向 飞流れる電流密度を $\dot{I}_{i, h}$ とする之， $\dot{I}_{i, h}$ は素線断面 を均一に流れるとした相電流とうず電流との合成電流 密度であらわせるので，

$$
\dot{I}_{i, h}=\left(4 / \pi d^{2}\right) \dot{a}_{h} I_{X}+\dot{I}_{x i}
$$

この $\dot{I}_{i, h}$ 用いて, 素線 $S_{i, h}$ の単位長当りの発生 損失 $p^{(i, h)}$ 汃次式で計算される。

$$
p^{(i, h)}=2 \rho \int_{-d / 2}^{d / 2}\left|\dot{I}_{i, k}\right|^{2} \sqrt{(d / 2)^{2}-x^{2}} d x
$$

(2)，(10)㧍よび(11)式の関係を(12)式に代入し， (12)式の皘分を実行する之,

$$
\begin{aligned}
p^{(i, h)}= & \left(4 \rho / \pi d^{2}\right)\left(\alpha_{h}^{2}+\beta_{h}^{2}\right) I x^{2} \\
& +\left(\pi \omega^{2} / 4 \rho\right)\left(\mu u d^{2} / 16 \pi\right)^{2} \\
& \times\left[\left\{\sum_{j=1}^{n}\left(w_{j, i-1}+w_{j, i}\right) \alpha_{j}\right\}^{2}\right. \\
& \left.+\left\{\sum_{j=1}^{n}\left(w_{j, i-1}+w_{j, i}\right) \beta_{j}\right\}^{2}\right] I_{X^{2}}
\end{aligned}
$$

(13)式を $i$ 亿ついて平均すると，第 $h$ 周の素線 1 本 の笚位長当りの損失 $\bar{p}^{(h)}$ が求まる。

いま,

$$
\begin{aligned}
f_{i}= & \left\{\sum_{j=1}^{n}\left(w_{j, i-1}+w_{j, i}\right) \alpha_{j}\right\}^{2} \\
& +\left\{\sum_{j=1}^{n}\left(w_{j, i-1}+w_{j, i}\right) \beta_{j}\right\}^{2}
\end{aligned}
$$

とおけば，図2を参照して

$$
\begin{aligned}
& \bar{p}^{(h)}=\left(4 \rho / \pi d^{2}\right)\left(\alpha_{h}^{2}+\beta_{h}^{2}\right) I_{X}^{2} \\
& +\left(\pi \omega^{2} / 4 \rho M_{h}\right)\left(\mu u d^{2} / 16 \pi\right)^{2} \\
& \times\left[m_{h} f_{h}+2 f_{h+1}+\cdots+2 f_{2 n-h-1}\right. \\
& +\left\{M_{h}-m_{h}-2(2 n-2 h-1)\right\} \\
& \left.\times f_{2 n-n}\right] I_{X^{2}}
\end{aligned}
$$

$\left(h=1,2, \cdots, n\right.$, 但し, $h=n$ の場合 $M_{n}=$ $m_{n}=1$ で右辺〔つの第1項までをとる)

次に， $X$ 相導体全体で発生する交流損失を単位長当 bPx とすると

$$
P_{X}=u\left\{\sum_{h=1}^{n} M_{h}\left(1+k_{h}\right) \cdot \bar{p}^{(h)}\right\}
$$

但し， $k_{h}$ は第 $h$ 周の琹線のより込率である。 従って，X相導体の龺位長当りの交流実効抵抗を $R_{A C X}$ とすると，(15)拉よび(16)式の関係を用いて， $R_{A C X}=P_{X} / I_{X}^{2}$ から $R_{A C X}$ が計算できる。また $R_{D C X}$ は,

$$
\frac{1}{R_{D C X}}=\frac{\pi d^{2} u}{4 \rho} \sum_{h=1}^{n}\left\{M_{h} /\left(1+k_{h}\right)\right\}
$$

とあらわせるので，表皮効果係数 $\lambda\{=($ 交直抵抗比一 1) $\times 100 \%\}$ は次のよう亿求まる。

$$
\begin{aligned}
\lambda / 100= & u^{2}\left[\sum_{h=1}^{n}\left\{M_{h} /\left(1+k_{h}\right)\right\}\right] \\
& \times\left\{\sum_{h=1}^{n} M_{h}\left(1+k_{h}\right)\left(\alpha_{h}{ }^{2}+\beta_{h}{ }^{2}\right)\right\} \\
& +\left(\omega \mu u^{2} d^{3} / 64 \rho\right)^{2} \\
& \times\left[\sum_{h=1}^{n}\left\{M_{h} /\left(1+k_{h}\right)\right\}\right] \sum_{h=1}^{n}\left(1+k_{h}\right) \\
& \times\left[m_{h} f_{h}+2 f_{h+1}+\cdots+2 f_{2 n-h-1}\right. \\
& +\left\{M_{h}-m_{h}-2(2 n-2 h-1)\right\} \\
& \left.\times f_{2 n-h}\right]-1 \ldots \ldots \ldots \ldots \ldots \ldots \ldots \ldots \ldots \ldots
\end{aligned}
$$

$\left(h=1,2, \cdots, n\right.$, 但し, $h=n$ の場合 $M_{n}=m_{n}$ $=1$ とし，右辺の中の $\left[m_{h} f_{h}+2 f_{h+1}+\cdots\right]$

は第 1 項のみをとる)

(18)式で $\lambda$ を計算するためには，より込率 $k_{h}(h=$ $1,2, \cdots, n)$ のデータを必要とする。しかし，通常 $k_{h} \ll$ 1 であり，kh の平均值を $k\left\{=\left(\sum_{h=1}^{n} k_{h}\right) / n\right\}$ とすると, (18)式において $\sum$ 記号の中に入っている $\left(1+k_{h}\right)$ お よび $1 /\left(1+k_{k}\right)$ はそれぞれ近似的に $(1+k)$ および $1 /$ $(1+k)$ として $\Sigma$ 記号の外一出せるので，各素線のよ り込率を考慮せず，次式で $\lambda$ を計算しても实用上差支 えない。すなわち

$$
\begin{aligned}
& \lambda / 100=u^{2}\left(\sum_{h=1}^{n} M_{h}\right)\left\{\sum_{h=1}^{n} M_{h}\left(\alpha_{h}^{2}+\beta_{h}^{2}\right)\right\} \\
& +\left(\omega \mu u^{2} d^{3} / 64 \rho\right)^{2} \\
& \times\left(\sum_{h=1}^{n} M_{h}\right) \sum_{h=1}^{n}\left(m_{h} f_{h}+2 f_{h+1}+\cdots\right. \\
& +2 f_{2 n-h-1}+\left\{M_{h}-m_{h}-2(2 n\right. \\
& -2 h-1)\} f_{2 n-h]}-1
\end{aligned}
$$

表皮効果係数を与える上記(19)式は，現穾の導体に 
おりる素線配列を忠実に反映しているので，導体仡 ズの㚼何とかかからず，正確な $\lambda$ が算出できる。とこ ろが，従来報告されている分割導体の表皮効果係数算 出理墖では，各々のセグメント導体（扇形）を断面皘 が等しい等価円䄇に置換するという近似を導入してい る(6)。合回著者らが新しく導出した(19)式では，その ような近似を全く排除している点が特長といえる。こ のととを応用の観点加らみれば，ミクロな素線配列の 差暴が表皮効果係数化与える影響を直接計算に上って 明らかにすることが可能になったということである。

すなわち，特に構造設計の面で自由度の大きい大サ イズ導体の最遵設計を行なう場合に本理諭の偉力が発 揮されるといえよう。

上記のととに関連した具体的な計算は，あとの第 4 章で行なうが，その前に上記理論の妥当性を検証する ための実験を行なった。これを次章に記述する。

\section{3. 実導体における理論值と実測値の比較}

前述の理論式の妥当性を検証するため，実規模の素 線絶縁分割大導体を試作し，種々の導体温度（導体の 温度上昇は，通電による）で交流実効抵抗を実測し， 理論值と実測值との比較を行なった。なお，理論計算 你しては，実導体の断面形状を観察した結果加ら表 2 (a)のケース 3 に示す素線配列を使用した。

〈3.1〉試 料 断面積が， $5,500 \mathrm{~mm}^{2}$ の素線絶 縁分割導体 (導体外径: $101.8 \mathrm{~mm}$, 導体内径: 38.0 $\mathrm{mm}$ ，分割数：9，周の数：6，材質：銅）を武作した。 各素線の絶緣皮膜材としては，ボリビニルホルマール

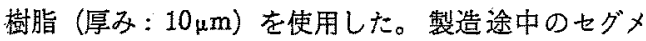
ント成形後扔よざ導体集合後の完成品 $($ 約 $10 \mathrm{~m}$ ) でて れらの素線間の抵抗をテスターによって測定したが， いずれも $10 \mathrm{M} \Omega$ 以上であり，各素線間が完全隹絶縁 されていることを確認した。

$\langle 3 \cdot 2\rangle$ 測定方法 交流実効抵抗の測定は，一般 飞導体に交流を通電することによって行なわれるが， 電気的な測定に際しては，電厈および電流の測定用リ 一ド線に電磁誘導が重疊するととから測定に誤差が生 ずる可能性がある。また，交流電力計のように力率の 低下が誤差の要因となる測定器むあり，現在まで報告 例(7) (9) はあるもののいまだ標準的な方法が確立され ていない。従って，今回特に従来にない大サイズの導 体について測定するととを考慮して，次の (1)，(2) の電気的測定法に加えて，(3) 亿示す熱的測定法をす 採用した。

(1) 交流電位差計法

(2) 交流電力計法

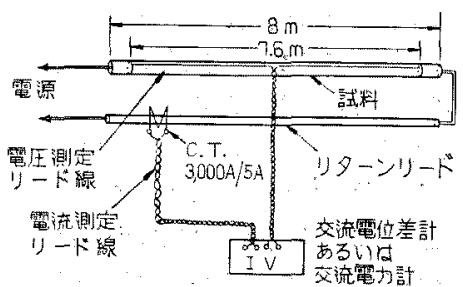

図 4 交流実効抵抗の測定回路 (電気的な測定方法)

Fig. 4. AC resistance test circuit.

(3) 温度餲和法

(1)扔よび(2)の测定方法では，図4亿示す上うに 測定点両端加らの電圧測定用リード線を導体の直上に 密着して沿わせ，試料の中央でより合せて測定器まで 配線した。電圧測定有効長としては, 導体のより合わ せピッチと測定スペースの制約を考虑して，3ピッチ の約 $7.6 \mathrm{~m}$ とした。また電流测定用リード線もC.T. から測定器まで同様により合わせ配線するととによっ て，極力電磁誘導の影響を受りなくなるようにした。 導体の温度は尊体に交流を通電することによって上昇 させ，導体表面はけい酸塩を主成分とした断熱材（約 $25 \mathrm{~mm}$ 厚) で保温した。なお，交流電力計の力率によ る誤差は，測定電生之測定電流の位相差が約 $71^{\circ} \sim 72^{\circ}$ であったため，約 $0.2 \%$ 以下で無視できる範囲であ った。(3)の温度飽和法では，熱抵抗が既知の上記断 熱材を使用した（実際には，導体の直流抵抗の測定の 際，直流通䉝時の導体の温度上昇加ら熱抵抗を算出し ておく。また熱抵抗の測定は，精度を考虑し温度上昇 幅を大きくとりうるよう導体に $2,000 \mathrm{~A}$ 以上の電流を 通電し，導体温度 $50^{\circ} \mathrm{C}$ 以上で行なったり。弓して導 体に交流を通電し，導体温度上杽が飽和した状態で温 度上昇值之電流值加ら交流実効抵抗を算出した。

この测定方法では，上述の電気的測定方法の上うな 電磁誘導などによる測定誤差は入らない。一方，断熱 材の熱抵抗か断熱材の温度によって变化すること，導 体長さ方向にわたって温度が一定でないなどのために 誤差を生じる可能性がある。しかし，測定した導体の 温度範囲約 $50^{\circ} \mathrm{C} \sim 85^{\circ} \mathrm{C}$ 亿対して, 導体長さ方向にわ

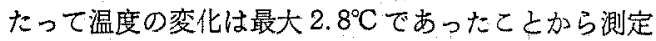
結果への影響は無視できる程度であった。

$\langle 3.3\rangle$ 理諭值と実測值の比渂 !前記 3 測定方法 による実測值を因 5 に導体温度と表皮效果係数の関係 として示した。交流電位差計と交流電力計による実測 值はほぼー致しているが；温度飽和法行よる実測值は これら電気的測定法に比較し，各導体温度について約 $25 \%$ 低い値を示している。この差異の原因について 
は，明確に示すととは困難であったが，央用上の問題 である交直抵抗比ではこの差は約 $4 \%$ 相当であり，実 用上は許容し得る範囲と考える。

理諭値の力は，表 2 (a)のケース 3 亿示すような素 線配列に対し計算して得たものである。困 5 に示すよ うに3 測定方法による実測值のはは中間に理論值が存 在することから，実用面から妥当な值であると考え る。電力ケーブルの導体の素線配列は，一般に本計算 法で用いた配列よりあ複雑である。しかし，このよう

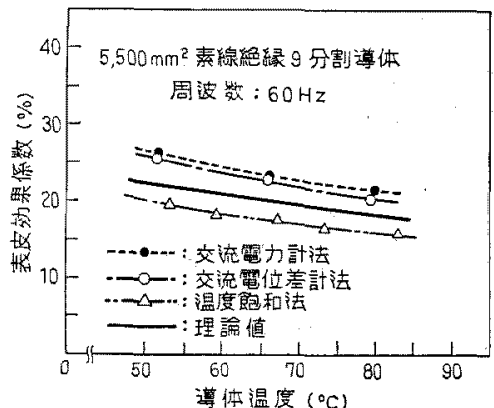

図 5 表皮効果係数の㬰測値亡理論値との比較

Fig. 5. Measured versus calculated skin effect coefficient.

表 2

Table 2.

（a）素線配列のデータ（因 5 〜国 8 の計算化使用）

(a) Formation of strands used for calculation of Fig. 5 8.

\begin{tabular}{c|c|c|c|c|c|c|c|c|c|c|c|c|c}
\hline & \multicolumn{3}{|c|}{$M_{k}-m_{k}-2(2 n-2 h-1)$} & \multicolumn{1}{|c|}{$m_{k}$} \\
\hline $\begin{array}{c}\text { ケー 周 No. } \\
\text { No. }\end{array}$ & 1 & 2 & 3 & 4 & 5 & 6 & 1 & 2 & 3 & 4 & 5 & 6 \\
\hline 1 & 10 & 7 & 6 & 5 & 3 & 1 & 2 & 3 & 2 & 1 & 1 & 1 \\
\hline 2 & 9 & 8 & 6 & 5 & 3 & 1 & 3 & 2 & 2 & 1 & 1 & 1 \\
\hline 3 & 9 & 7 & 6 & 5 & 3 & 1 & 3 & 3 & 2 & 1 & 1 & 1 \\
\hline 4 & 9 & 7 & 7 & 5 & 3 & 1 & 3 & 3 & 1 & 1 & 1 & 1 \\
\hline 5 & 9 & 7 & 6 & 6 & 3 & 1 & 3 & 3 & 2 & 0 & 1 & 1 \\
\hline 6 & 9 & 7 & 6 & 5 & 4 & 1 & 3 & 3 & 2 & 1 & 0 & 1 \\
\hline
\end{tabular}

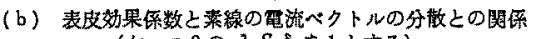
(ケース $3 の \lambda, S, \delta$ をする)

(b) Effect of $S$ and $\delta$ defined in equation (18) on the skin effect coefficient.

\begin{tabular}{|c|c|c|c|}
\hline $\begin{array}{c}r-x \\
\text { No. }\end{array}$ & $\begin{array}{c}\text { 表皮奻果䋆数 } \\
\lambda \text { (相対値) }\end{array}$ & 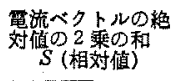 & 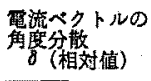 \\
\hline 1 & 1.41 & 1.06 & 1.12 \\
\hline 2 & 1.05 & 1.01 & 1.04 \\
\hline 3 & 1 & 1 & 1 \\
\hline 4 & 0.94 & 0.99 & 0,995 \\
\hline 5 & 0.92 & 0.987 & 0.95 \\
\hline 6 & 0.90 & 0.985 & 0.94 \\
\hline
\end{tabular}

に比較的単純な配列で十分実用的な表皮效果係数を推 測できることが確認できたので，以下との配列で導体 の最適棈造を模索することとした。また，素線配列の 差巽が，表皮效果係数に与える影響につ心ても次章で 考察する。

\section{4. 檤体の構造と表皮効果係数の関係}

埒体の構造は，最終的には製造上や布設上の制約な ども考慮の上で決定されるが, 素線絶縁の効果が著し くなる大導体ほど構造設計上，即ち分割数，導体内外 径比，菜線本数なよ゙の自由度が大きくなる。本章では 表皮效果に及淄す諸要因つまり導体断面積, 分割数, 導体内外径比, 素線配列, 周の数之表皮效果係数亡の 関係について検討した。

$\langle 4 \cdot 1\rangle$ 導体断面積と表皮効果係数の関係 素線 絶縁分割導体末上び通常の素線非絶縁導体の表皮効果 係数の導体断面積に対する関係老図 6 亿示す。通常の 導体の表皮効果係数は，JCS の計算式 ${ }^{(4)}$ に徒った。ま た，案線絶縁分割導体の内外径比は，今回試作の導体 と同様の 0.373 とした。因6 から絜線絶䜌の効果は， 顕著であることがわかる。周波数が $60 \mathrm{~Hz}$ の場合，今 回試作した $5,500 \mathrm{~mm}^{2}$ の素線絶縁 9 分割導体の表皮 効果係数は，従来の素線非絶縁 6 分割導体の表皮効果 係数約 58\% に対し約 18\% に低減する。これは，送電 容量にして約 16\%の向上に相当するので素線絶縁の 効果は大きい之言える。また実用サイズの $2,500 \mathrm{~mm}^{2}$ です，表皮教果係数は約 $19 \%$ 加ら約 $4 \%$ に低減する ことからやはり大幅な効果のあることがわかる。

〈4.2〉分割数およひ導体内外径比と表皮效果係数

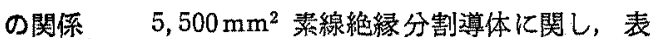
皮効果係数と分割数の関係を導体内外径比をパラメー

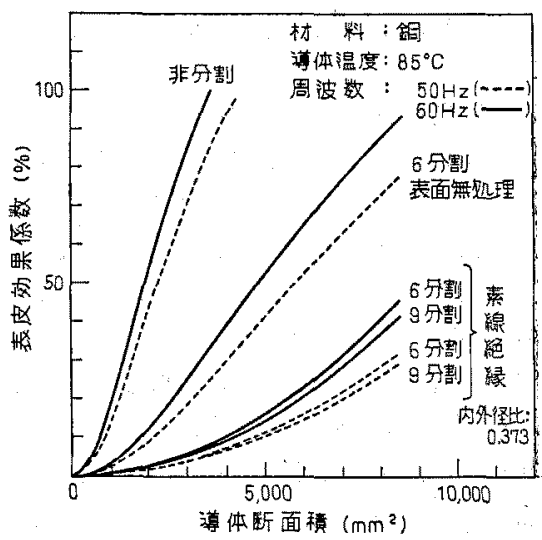

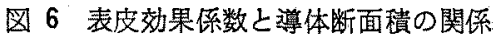
Fig. 6. Relation between skin effect coefficient and conductor size. 
タとして図 7 に示す。因から分割数が多くなるほど， 表皮効果保数は低減し，特に分割数が少ない領域では その傾向が著しいととがわかる。また分割数が 10 以 上では低淢の度合いに飽和の傾向があり，これ以上の 分割は余り勃果がない。一方，内外径比が大きいほど ，表皮勃果係数は大幅に低隇しその勃果は分割数の効 果よりも大きい。また周波数が $50 \mathrm{~Hz}$ 己 $60 \mathrm{~Hz}$ の場 合を比較すると, $50 \mathrm{~Hz}$ での内外径比: 0.5 と $60 \mathrm{~Hz}$

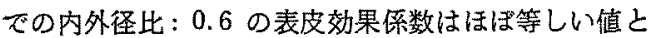

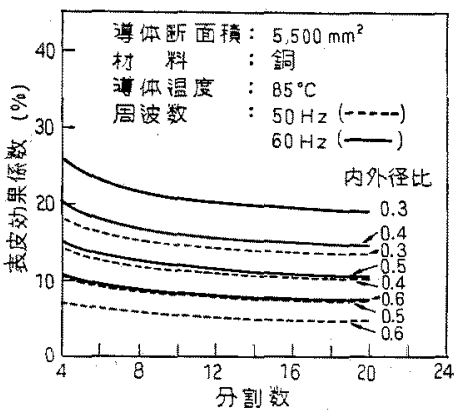

困 7 導体構造已表皮効果係数の関係

Fig. 7. Relation between skin effect coefficient and conductor structure.
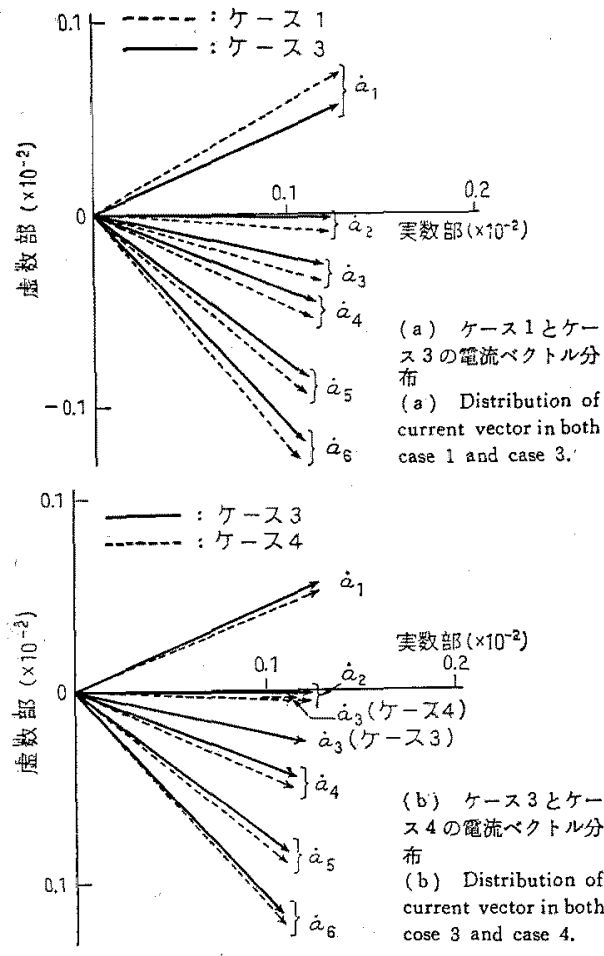

㘣 8

Fig. 8.
なる。従って周波数の相違が，導体の構造毁計に大き な影響を及活す可能性があると,とがわかる。

〈4.3〉 素線配列之表皮効果係数の関係 5,500 $\mathrm{mm}^{2}$ 素線絶縁 9 分割導体化関し，表 $2(\mathrm{a})$ のケース 1 6 亿示すように，素線配列を変化した場合の表皮 勃果係数を表 2（b)に示す。但し，表 2（b)ではケー ス 3 の表皮奻果係数の值を 1 として相対比較を行なっ た。との素線配列之表皮効果係数の関係を考察するた め, 各周どとの素線 1 本に流机る電流 $\dot{a}_{j}$ のベクトル 分布をケース 1，3，4行き，四8(a)，(b)飞示す。 図 8（a ，，(b) 加ら同周内の最内層の素線 1 本を該当 する周の最外通に移行させると周の電流ベクトルは位 相が進むことがわかる。ところが，素線の位置が変化 しても他の周の電流ベクトルは(4)式佰すよう， 全ての周の電流べクトルの総和が一定であるように変 化する。そのために同図（a）のケース1の場合は，ケ ース 3 と比較して電流ベクトルの相対的な位相差が增 加している。同四（b）の場合は，(a)とは反対にケス4の方がケース 3 上りあ電流ベクトルの位相差は減 少している。この電流ベクトル間相互の位相差が電流 ベクトルの分散の程度を示すあのであり，乙れは定量 的に各周の笔流ベクトルの絶対值の 2 乗の総和 $S$ お 上び各周の電流ベクトルの角度総和 $\delta$ で次式の上うに あらわせる。

$$
S=\sum_{h=1}^{n} M_{h}\left(\alpha_{h}{ }^{2}+\beta_{h}{ }^{2}\right), \delta=\sum_{h=1}^{n} \arg \left\{M_{h}\left(\alpha_{h}+j \beta_{h}\right)\right\}
$$

この分散量 $S$ と $\delta$ をケース1からケース 6 亿つい て計算した結果を，表皮勃果係数の場合之同樣にケ一 ス3 の値を1 とし表 2 (b) 亿示す。同表(b)加ら分散 量 $S$ および $\delta$ が小さいほど，表皮効果係数は低隇す ることがわかる。また最外周の素線配列の変化が，表 皮効果係数认最も大きな影響を与えるとともわ加る。 なお，(20)式で定䓔した分散量 $S$ は，(19)式の右辺 の第 1 項の中にあらわれて招り，結局ての值が常温以 上の銅あるいはアルミ導体の表皮効果係数に大きな影 響を与えていると言える。

〈4.4〉周の数と表皮効果係数の関係 $5,500 \mathrm{~mm}^{2}$ 素線絶縁 9 分割導体関し，表皮効果係数之周の数の 関係を表 3 の素線配列設計例に従い，計算した結果を 図 9 亿示す。周の数が多くなると，実際上考元られる 素線配列の組み合わせが堌加し，配列の盖異によって 表皮効果保数が変化するととが予想される。

従って，実際の導体の表皮効果保数の評価は，表 3 に示すような現実に考えられる導体の素線配列のすべ ての組み合わ甘に対して計算した表皮効果係数の值を 
平均化するこしによって行なうのが妥当である。こと

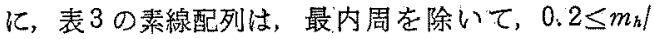
$\left\{M_{h}-m_{h}-2(2 n-2 h-1)\right\} \leq 0.5$ とした。

図 9 から，周の数が多いほど表皮効果保数は低減し

表 3 㨞線配列のデータ(図 9 の計算に使用)

Table 3. Formation of strands used for calculation of Fig. 9 .

\begin{tabular}{|c|c|c|c|}
\hline 周の数 & 周の瑟号 & $M_{h}-m_{h}-2(2 n-2 h-1)$ & $m_{n}$ \\
\hline \multirow{4}{*}{4} & 1 & 6 & 2 \\
\hline & 2 & 5 & 1 \\
\hline & 3 & 3 & 1 \\
\hline & 4 & $\because$ & 1 \\
\hline \multirow{5}{*}{5} & 1 & 7,8 & 3,2 \\
\hline & 2 & 6 & 2 \\
\hline & 3 & 5 & 1 \\
\hline & 4 & 3 & 1 \\
\hline & 5 & 1 & 1 \\
\hline \multirow{6}{*}{6} & 1 & $8,9,10$ & $4,3,2$ \\
\hline & 2 & 7,8 & 3,2 \\
\hline & 3 & 6 & 2 \\
\hline & 4 & 5 & I \\
\hline & 5 & 3 & 1 \\
\hline & 6 & 1 & 1 \\
\hline \multirow{7}{*}{7} & 1 & 10,11 & 4,3 \\
\hline & 2 & 8. 9,10 & $4,3,2$ \\
\hline & 3 & 7,8 & 3,2 \\
\hline & 4 & 6 & 2 \\
\hline & 5 & 5 & 1 \\
\hline & 6 & 3 & 1 \\
\hline & 7 & 1 & 1 \\
\hline \multirow{8}{*}{8} & 1 & $11,12,13$ & $5,4,3$ \\
\hline & 2. & $.10,11$ & 4,3 \\
\hline & 3 & $8,9,10$ & $4,3,2$ \\
\hline & 4 & 7,8 & 3,2 \\
\hline & 5 & 6 & 2 \\
\hline & 6 & 5 & 1 \\
\hline & 7 & 3 & 1 \\
\hline & 8 & 1 & 1 \\
\hline
\end{tabular}

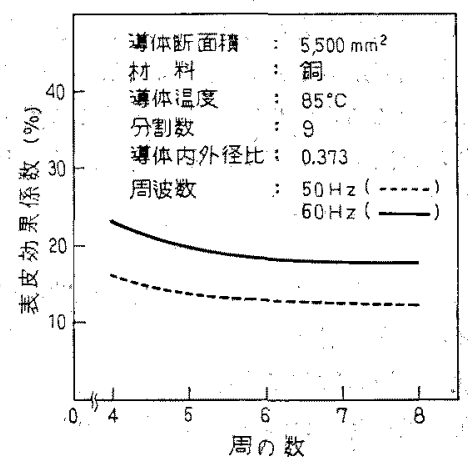

図 9’周の数之表皮效果係数の関係

Fig. 9. Relation between skin effect coefficient and the number of strand layers.
特に周の数が 4〜6でその傾向は著しく，6 周以上の 周の数では飽和の傾向があることがわかる。

\section{5.むすび}

電力ケーブル用の分割導体は素線をより合わ甘薪形 に圧縮成形したセグメント導体を更认集合した復雑な 多導体構造である。との分割導体の交流実效抵抗の計 算式は，JCS-168号などに適用範国の限られる半経験 式が示されているものの(4)(5)，理論式は確立されてい ない。そこで，本論文では導体の形状およで素線配列 に関する情報を正確に計算式の中にとり入れた坔線 絶縁分割導体の新しい交流実効抠抗の理諭式を導出し た。また， $5,500 \mathrm{~mm}^{2}$ の素線絶縁 9 分割導体の交流実 効抵抗を測定し，理論値と比較した結果，理論式の妥 当性が検証できた。

次に，本理論式を用いて蒵線絶縁分割導体の表皮效 果俰数を算出し, 結果を䀨面積, 分割数, 内外佳比, 周波数，素線配列，周の数などとの関係で示し，最適 構造を模索した。特に素線配列との関係については， 素線の電流ベクトルの分散を考察することによって説 明した。

以上，素線絶縁分割導体の交流実效抵抗の新しい理 諭計算法を紹介し，乙の実用性を確認した。

(昭和 57 年 1 月 25 日受付，同 57 年 9 月 28 日再受付)

\section{文献}

（1）杉山，他：「笔力ケーブル用大サイズ導体の表皮效果」昭 52 露気学会事京支部太 No. 121

（2）杉山，仳: 「圆絶緑分割运体の開発」昭 54 電気学会東京支部 大 No. 139

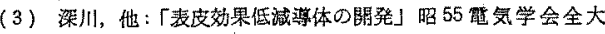
No. 587

（4）日本電線工業会：「電力ケーブルの許容電流」JCS，第 168 号D (昭 55)

(5) J.H. Neher \& M. H. McGrath: "The Calculation of the Temperature Rise and Load Capability of Cable Systems", Trans. Amer. Inst. Elect. Engr., 76. (pt. III), p. 752 (Oct. 1957)

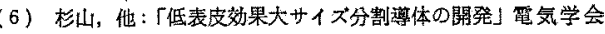

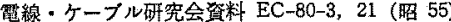

(7) C. Katz, et. al. : "Progress in the Determination of $\mathrm{AC}$ / DC Resistance Ratios of Pipe-Type Cable Systerns", IEEE Trans. Power Apparatus Syst., PAS-97, No. 6, p. 2262 (Nov/Dec, 1978)

(8) M. Takaoka, et. a1.: "Development of Flexible Joint for Large Capacity Submarine O.F. Cable", IEEE 1979 PES Summer Meeting, F 79, 611-5 (1979)

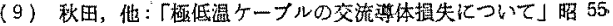
筐気学会全大 No. 1126 